\title{
Phobias of Russians in the Paradigm of "General and Special"
}

\author{
Nadezhda Bagdasaryan \\ Bauman Moscow State Technical University \\ ULK 2/18 Rubtsovskaya Embankment \\ Moscow, Russia 105005 \\ E-mail:ngbagda@mail.ru
}

\author{
Marina Korol \\ State University "Dubna" \\ 19 Universitetskaya St. \\ Dubna, Moscow Region, Russia 141982 \\ E-mail: marina.korol4@gmail.com
}

\begin{abstract}
The article deals with the problems of modern socio-cultural reality and the associated state of human anxiety, which is reflected in the nature of its fears. The specifics of the fears of Russians peculiar to the "traumatized society" are revealed, where the split, contradictoriness and deformation of social development dominate. This condition deprives society of the potential for creation. On the basis of this, a conclusion is made about the responsible role of the political elite in the goal-setting of the development of the nation and the return to it of the energy "aspiration for the future".
\end{abstract}

Keywords-fear; future of humanity; forecasting; post-Soviet Russia; "traumatized society"; political elite

\section{INTRODUCTION}

Is it possible to identify the dominant trend, the key characteristic of the state of modern society in the spectrum of questions that modern humanity is asking for? The society is more and more complex, non-linear, transitive, which puts every person in a situation of a challenge. The search for an answer leads to an understanding that anxiety has become the leitmotif of the life of the personality, society, and the global world.

At the frontier of XX-XXI century humanity has entered the territory of permanent crisis caused by systemic contradictions and a violation of the techno-bio-humanitarian balance. The world in a kaleidoscope of changing goals, priorities and values has become ephemeral and fragile, and a person is unprotected in the face of uncontrollable changes. Anxiety is a sign of modernity. It is generated by the fear of humanity facing the threats of the future.

Fear has always been a natural indicator of danger. He was also when the person had not yet realized himself as the "I". But "bright symbols of religious and metaphysical fear are left behind in this long road, new symbols appear that preserve something from religious trembling and something from metaphysical horror, but already interspersed with meaningful mind ... we see new meanings of fear that will allow us to understand the changes occurring in it" [1]. These meanings are connected with the realization that humanity has a chance to withstand the threats of the future if it finds ways to overcome its fear.

\section{ANXIETIES AND FEARS OF "LIQUID MODERNITY"}

Fundamental issues of human existence and its security have acquired a special shade of anxiety at the fracture of the XX-XXI centuries, which opened for society a problematic field of the systemic crisis. "Analysis begins when the world order collapses" [2]. The scientific reflection of the diverse forms of social life that are produced by network information media converging NBICS-technologies, allowed to define the morphology of society as "liquid modernity", where speed has become the main factor of social stratification and social domination[3].

Speed, destroying the actual grounds for establishing a firm chronological social order, creates a multidimensional space in which fragments of temporal modes are paradoxically mixed: past, present, aspiration for the future. V.S. Stepin noted, "in the process of self-development, the realized future has a reverse effect on the structures formed by the past"[4].

The entropy increases. In the theory of dynamical systems, entropy is considered as a number expressing the degree of randomness of its trajectories. Modern society, being a super complex system, literally impregnated with entropy, enters to the territory of systemic contradictions, the boundaries of which are delineated by instability and inability to self-regulation.

The horizons of the future as an era of global instability were discovered by the members of the Club of Rome back in the late 60s of the XX century, on the basis of a series of reports made by a number of prominent scientists under the general title "Humanity Difficulties". After almost half a century, one may ask: "What is the most dangerous for people in a wide range of problems presented to the world community"? Let us consider some of the positions.

The dichotomy: "man and nature". So the attitude of a person to the surrounding nature, aimed at actively transforming objects and subjecting them to man, gave rise to an irreconcilable contradiction with the biosphere and as a result an ecological crisis that took on a global and truly apocalyptic character. Before us, a society that is threatened to deprive itself of clean air and drinking water, a society that 
opens up the prospect of being in permanent anthropogenic and technological disaster and human ailments.

Arms race. Many modern events, such as the wars in Syria and Iraq, become the embodiment of the ideas of the early 1990s that were associated with the "revolution in military affairs". More and more advanced ballistic and cruise missiles are being invented, the combat management system is being modernized, strategic models of control over outer space are being developed. A stable feeling arises in the society that "it is unlikely that the desire to rely more and more on high technologies - both for achieving military goals and for ensuring security - is likely to decline" [5].

This is evidenced by research conducted by the Stockholm International Peace Research Institute (SIPRI), which states that the United States is the country with the highest annual military spending in the world [6]. Russia does not lag behind the United States, because it is among the five states that spend the most money on the military budget. In the address of the Russian President V.Putin to the Federal Assembly noted that "the equipment of the Armed Forces with modern weapons has increased 3.7 times. More than 300 new models of military equipment were accepted for service ... The number of medium-range high-precision weapons carriers increased more than 12 times, and precision-guided cruise missiles increased more than 30 times"[7].

Information technology, virtual reality, anthropological metamorphosis.

The mega space of the Internet, impulses and accelerating dynamics, makes society mobile, unprecedentedly complicating social reality, forming an alternative virtual world to it as a new type of symbolic existence of man and society, often turning into the absorption of human consciousness and its manipulation. A "social anthropological type is born, which should be called a frontier man - a person existing between the real and virtual level of socio-culture, in the created world of illusions" [8].

But perhaps the most dangerous is the opacity, instability and chaos of public life, where the gap between the rich and the poor is widening, entailing "significant differences in social opportunities, which creates a constant and deep conflict of social interests that is projected onto the political level"?[9]

Obviously, it is not possible to single out the most dangerous in this series of vulnerabilities and disasters, all of these are links in one chain, because a modification of nature, society, techno-sphere, which previously represented an independent reality, now form a single whole - sociobiotechnical systems (SBT systems ). "The global SBT system is risky in its essence, since it consists of different quality elements having their own dynamics, rhythms of internal transformation ("aging"), expiration dates; these elements require constant monitoring..." [10].

Analysis of new phenomenology and related problems of social development allows modern science, which inherits the core of the methodological program of classical scientific foresight, to consider the future through prognostication procedures. In scientific research, interpretation of concepts is of great importance. Thus, scientific foresight is reduced to "prediction procedures as a logical or mathematical calculation based on universal knowledge and verified empirical data" which are effectively practiced in the field of exact natural and technical sciences[11]. The prediction is aimed at establishing some fact. The forecast fixes an object in its prospective development. What are the forecasts for humanity?

After discoveries in quantum cosmology, the prospects for the development of mankind cannot be considered outside the context of the history of the universe, with which its history is inextricably linked. And since "the forecast is never neutral" in this connection the predictions of the English theoretical physicist Stephen Hawking sound more than not reassuring for humanity living on such a fragile planet as the Earth[12][13].

The man-nature dichotomy will lead to global warming, which will turn the Earth into a Venus with a temperature of +250 degrees Celsius and sulfuric acid rains. The arms race is a risk for humanity to disappear as a result of the Third World War. The creation of artificial intelligence will become the most important in the history of mankind, but it can prove to be the very last one, because entrusting it with fateful decisions means a catastrophe. After all, artificial intelligence will be created in the image and likeness of the human and therefore it will be practically impossible to calculate its thought processes. The prediction of Stephen Hawking fully coincides with the troubling thoughts about the future of mankind, Norbert Wiener, the founder of cybernetics and the theory of artificial intelligence: "We are, in the most direct sense, shipwrecked passengers on a doomed planet" [14].

The contours of the future are blurred, and seem completely unpromising for the volatile, complex in its multiplicity, but unified in fear of the future of the human world. Fear is all-pervasive, becomes part of the being of mankind, penetrate into the daily life of all social strata. Deep stress, turning into a natural state of people, creates the phenomenon of "collective anxiety rooted in economic and political uncertainty, social problems and security threats of different genesis and intensity" [15].

But in every particular society, fears can tell a lot about society itself.

\section{RUSSIANS: FEARS OF TRAUMATIZED SOCIETY}

One of the most outstanding representatives of existentialism, K. Jaspers, concerned about the fate of spirituality in a crisis era, the confrontation between man and impersonal power, the meaning, origin and purpose of human history, wrote that fear "is multifaceted and heterogeneous. It is not only a superficial and quickly erased memory of fear and not only deep and gnawing fear, hidden or obvious, it is on a vital or existential level and seems to contain all kinds of fears"[12]. In the modern world, it takes on global forms. In the context of a global peace, where fear perception dominates, there are also Russians. But for them, 
this condition is greatly exacerbated by the problems of their own internal development.

Post-Soviet Russia is a new social reality that has evolved over a quarter of a century on the basis of radical shifts in the collapse of the social structures of the socialist system. The consequence of these processes was not only the creation of the infrastructure of market relations and the establishment of the foundations of democracy, but also traumatic social changes in the forms of new risks and threats, deterioration of living conditions. The socio-cultural reality of Russian capitalism shows itself to be extremely complex, contradictory, and explosive. In its depths a peculiar "phenomenon of centaur" is born, embodying "the incompatibility of different origins, the combination of the incompatible"[16] [17]. This is largely due to the fact that the transformation of Russia into a new capitalist country of the post-communist bloc was connected with privatization, conducted quickly, in a closed mode. With great speed bowels of the earth were handed out for a pittance: oil, nonferrous metals, diamonds, coal, and production.

\section{But who became the owner of the country's wealth?}

All that was created by the labor of several generations of Soviet people, turned out in the hands of a narrow group of individuals.

"Only $8 \%$ of Russians believed that privatization was carried out" in the interests of the working people". In the opinion of almost a quarter of the population - «in the interests of the commercial mafia" and in "the interests of state officials" (27\%)" [18]. Thus, the neo-liberals who initiated privatization contributed to the emergence of an abnormal economy that was not oriented toward creating new consumer goods, but rather to appropriating previously created wealth. On the basis of the merging of criminal structures with the bureaucracy, a new scale of stratification was formed based on class grounds, in which the natural characteristic of capitalism is manifested - generating inequality in incomes. Although social inequality is an ageold attribute of society, even in the USSR, in the country of victorious socialism, there was a gap between the incomes of the population. But the gap between the poorest and the richest citizens was relatively small by 3-5 times. In postSoviet Russia for the period 1990-2013 the gap increased to 16.6 times. If we take into account that the official statistics of the Federal State Statistics Service do not include incomes of people from the poorest sections of society and data on the incomes of the richest Russians, then «taking into account hidden revenues, the gap can reach 40-50 times or more. If we compare the level of inequality in Russia with the "traditionally" capitalist countries of Western Europe, then these countries look quite "socialist". Thus, the differential ratio of Denmark, Finland and Sweden is at 3-4 times the gap; in Germany, Austria and France - is at 5-7 times; in the United States - about 10-12"[19].

But maybe, despite all the difficulties, a quarter of a century of reforms have given a positive result and it should be said that the goal - the creation of a national economy from the standpoint of sustainable economic growth as the basis for the reproduction of social welfare, justified the means?

Analysis of the lessons of Russian modernization shows that over the years of reforming, Russia has lost half of its economic potential. The indicator of genuine progress (GPI) acts as a gauge of the economic, social and ecological wellbeing and real well-being of the population. And if you turn to the annual report of the World Economic Forum 2017 2018, which builds a global competitiveness rating based on this indicator, then Russia occupies only 38th place in this rating [20]. Although the analytical group of the World Economic Forum also noted that Russia is emerging from the recession of $2015-2016$, has improved its position on five indicators, but its economy is still heavily dependent on the export of minerals and therefore the prospects remain uncertain.

Not surprisingly, against the background of this indicator, the main concerns for Russians are the problems of the socio-economic plan: the growth of tariffs for housing, utilities, the quality of medical services, low salaries, pensions and poverty. As shown by the all-Russian survey conducted in 85 subjects of the Russian Federation, about $50 \%$ of the population are very concerned about these problems, the same ones that these problems do not disturb, no more than $16 \%$. The specifics of sources of anxiety are reflected in the nature of fear, its increasing social determinacy: "The situation when respondents are afraid of 25 positions, and the level of fears for some of them reaches $70 \%$ or higher, makes you think about the state of health of the whole society" [21].

The greatest indicators of fears of Russians are associated with fears for the welfare of their families, for the future of children. This is due to the fact that for twenty-five years people have been deprived of the instruments of protection of the social state. In addition, the realities of capitalist society are now associated with fundamentally new forms of deviation that do not have cultural roots in our country: drug addiction, kidnapping, trafficking in human organs, gambling, terrorism.

And if earlier the future was associated with the belief that children will be happier than their parents, now the older generation, because of "current" fears and cataclysms, idealizes the past, seeing in it social happiness.

However, the Soviet past seems to be an anachronism for a new generation that has grown on the cultural patterns of the "new" Russian capitalism. Between generations, who do not have a common language, full communication is impossible. This phenomenon can be called a "vertical gap". "A person becomes an atomic, not included in intergenerational vertical and horizontal social networks, feeling lack of support, loneliness and existential vacuum: who am I, where and where am I going"? [22]. Society, torn horizontally and vertically, comes to the point of lack of adaptive opportunities, loss of sense of security and heightened anxiety, experiencing "fear of the future". 


\section{CONCLUSION}

Fear is an emotion, as it develops a person, mobilizes it for some action or, on the contrary, stops it. But when fear and anxiety become transcendent, they begin to play a negative role, they paralyze a person, and thereby deprive the society of the most important thing - the potential of aspiration for the future, creation. The traumatized society is not capable of implementing modernization projects.

In the implementation of modernization projects, the strategic vector chosen by the state is important: will it try to eliminate sources of anxiety and causes of fear, or use fear to strengthen the positions of political and business elites.

If the state in the person of the political elite cultivates democratic principles and ideals of the social state, it is able to minimize negative tendencies leading to destabilization, provide decent living conditions for the population and thereby neutralize the sources of anxiety and fears of people.

If the state only declares democratic transformation and seeks to satisfy its own interests without forming influential groups interested in creating social institutions that improve the lives of Russians, the index of trust to the state decreases, the gap between power and society deepens, social and economic inequality increases, raising the level existential fear.

However, understanding must also come of the fact that fear disorients and separates people, forms a sense of powerlessness, paralyzes the capacity for critical thinking and active civic action.

\section{REFERENCES}

[1] Kasumov T.K., Hasanova L.K. Fears in the life and life in the fear. VoprosyFilosofii. 2014. Vol. 1. P. 34-45. URL: https://dlib.eastview.com/browse/doc/38914678.

[2] Beck U. Life in the world society of risk: cosmopolitan turn // Bulletin of Moscow University. Series 12. Political Science. 2012. №5. P. 35-52. URL: https://dlib.eastview.com/browse/doc/28718785

[3] Bauman Z. Liquid Modernity. St. Petersburg: Peter, 2008. 240 p.

[4] The Analyses of Structure and Dynamics of Science in SocialCultural Context. Materials of the Discussion of V.S. Stepin's Selected Works // VoprosyFilosofii. 2017. Vol. 12. P. 5-31.. URL: http://vphil.ru/index.php?option=com_content\&task=view\&id=1834 \&Itemid $=52$

[5] Collins J., Fatter E. War and Technology // Russia in Global Politics 2016. № 2. Volume 14. P. 102-117. URL: http://dlib.eastview.com/browse/doc/46340635

[6] World military spending: Increases in the USA and Europe, decreases in oil-exporting countries. STOCKHOLM INTERNATIONAL PEACE RESEARCH INSTITUTE (SIPRI) URL: $\quad$ https://www.sipri.org/media/press-release/2017/worldmilitary-spending-increases-usa-and-europe

[7] The Message from the President to the Federal Assembly. March 1, 2018 URL: http://kremlin.ru/events/president/news/56957

[8] ShakirovaE.Yu., Listvina E.V. Modern sociocultural situation: anthropological metamorphosis // VoprosyFilosofii. 2018. Vol. № 1. P. 55-65. URL: https://dlib.eastview.com/browse/doc/50267501

[9] Lublinsky V. V. The Political dimension of social inequality and poverty (Comparative Experience) // POLIS. Political Studies. №5. 2015. P.94-106. URL: http://dlib.eastview.com/browse/doc/45515064
[10] Yanitskiy, O. Sociobiotechnical Systems: A New Approach to Humanity-Nature Interaction // Sociological science and social practice. 2016. vol. 4. No. 3. P. 5-22. 5 DOI: https://doi.org/10.19181/snsp.2016.4.3.4574.

[11] Pirozhkova S.V. Prediction, forecast, scenario: on question about diversity of prognostic research's results // Philosophy of Science and Technology. 2016. vol.21. №2. URL: https://iphras.ru/uplfile/root/biblio/ps/ps21_2/111\%E2\%80\%93129.p df

[12] Jaspers K. The meaning and purpose of history: Trans. from German. 2 nded. - M .: Republic, 1994. P.163. (Thinkers XX.).

[13] Stephen Hawking bequeathed to us: 7 of his main predictions about the future of humanity. URL: https://life.ru/t/ Stephen Hawking /1097536/kak_zavieshchal_nam_stivien_khokingh_7_iegho_ghlavny kh_proghnozov_o_budushchiem_chieloviechiestva?utm_source=LIF E.RU+correct\&utm_campaign $=26 \mathrm{fe} 9 \mathrm{a} 84 \mathrm{e} 5$ -

EMAIL_CAMPAIGN_2018_03_14\&utm_medium=email\&utm_term =0_d31dffbbf0-26fe9a84e5-112434401

[14] Viner N. Man the manager. St. Petersburg: Peter, 2001. URL: http://grachev62.narod.ru/wiener/wiener_2001.html

[15] Dutkiewicz P., Kazarinova D.B. Fear as politics // Polis. Political Studies . $2017 . \quad$ № $4 . \quad$ P. $8-21 . \quad$ URL: https://dlib.eastview.com/browse/doc/49212935

[16] ToshchenkoZh.T. Kentavrproblema (experience philosophical and sociological analysis): [Monograph] / Zh.T. Toshchenko. M . NoviyKhronograf, 2011. 536 p.

[17] Kravchenko S.A. Metamorphoses: essence, increasingly complex types, place in sociological of knowledge // Sociological Studies. 2017. №10. $\quad$ P. $3-14$ URL: https://dlib.eastview.com/browse/doc/49764571

[18] Gorshkov M.K. Russian society as it is: exploring survey data. Volume 1\&2.M .: NoviyKhronograf, 2016. P. 184.

[19] Kozyrev, GI. The conflict potential of contemporary Russian society // Sociological Studies. 2017. №6. P. 68-78. URL: https://dlib.eastview.com/browse/doc/48854590

[20] Global Competitiveness Report 2017-2018. URL: http://www.mpc.gov.my/wp-content/uploads/2017/10/GCR2017_bi.pdf

[21] Dolgorukova I.V., KirilinaT.Yu. MazaevYu.N., Yudina T.N. Social anxiety and social fears of Russias population: sociological dimension // Sociological Studies. 2017. №2. P.57-66. URL: https://dlib.eastview.com/browse/doc/48521078

[22] Emelin VA, TkhostovA.Sh. Deformation of the chronotope in conditions of sociocultural acceleration //VoprosyFilosofii. 2015. Vol. №2. P. 14-24. URL: https://dlib.eastview.com/search/pub/doc?art=0\&id=43285548. 